\title{
Erratum to: Development of a simple PCR-based assay for the identification of triazine resistance in the noxious plant common ragweed (Ambrosia artemisiifolia) and its applicability in higher plants
}

\author{
Kinga Klára Mátyás · János Taller • \\ András Cseh · Péter Poczai · István Cernák
}

Published online: 27 August 2011

(C) Springer Science+Business Media B.V. 2011

\section{Erratum to: Biotechnol Lett \\ DOI 10.1007/s10529-011-0714-5}

Unfortunately, the sentence "PCR was as follows: 1 cycle $94^{\circ} \mathrm{C}$ for $3 \mathrm{~min}$, followed by 35 cycles of $1 \mathrm{~min}$ at $94^{\circ} \mathrm{C}, 1 \mathrm{~min}$ at the primer annealing temperature and $1 \mathrm{~min}$ at $72^{\circ} \mathrm{C}$. A final extension was applied for 7 min at $72^{\circ} \mathrm{C}$." in the Materials and methods section has been misrepresented.

The correct sentence is:

"PCR was as follows: 1 cycle $94^{\circ} \mathrm{C}$ for $2 \mathrm{~min}$, followed by 45 cycles of $15 \mathrm{~s}$ at $94^{\circ} \mathrm{C}, 15 \mathrm{~s}$ at $53^{\circ} \mathrm{C}$ and $30 \mathrm{~s}$ at $72^{\circ} \mathrm{C}$. A final extension was applied for $3 \mathrm{~min}$ at $72^{\circ} \mathrm{C}$."

The online version of the original article can be found under doi:10.1007/s10529-011-0714-5.

K. K. Mátyás · J. Taller

Biotechnology Group, Department of Plant Science and Biotechnology, Georgikon Faculty, University of Pannonia, Festetics u. 7, Keszthely 8360, Hungary

A. Cseh

Department of Plant Genetic Resources and Organic Breeding, Agricultural Research Institute of the Hungarian Academy of Sciences, Brunszvik u. 2, Martonvásár 2462, Hungary

P. Poczai $(\bowtie)$

Plant Biology (Biocenter 3), University of Helsinki, PO Box 65, 00014 Helsinki, Finland

e-mail: peter.poczai@gmail.com

I. Cernák $(\square)$

Potato Research Centre, Centre of Agricultural Sciences, University of Pannonia, Festetics u. 7, Keszthely 8360,

Hungary

e-mail: i-cernak@ex1.georgikon.hu 